\title{
COMPARISON OF "D," "F," AND "W" GRADES BETWEEN INFORMATION SYSTEMS TRADITIONAL AND ONLINE COURSES FOR THE PAST FIVE ACADEMIC YEARS
}

\author{
Melody Alexander, Ball State University, malexander@bsu.edu \\ Allen Truell, Ball State University, atruell@bsu.edu \\ Edward Lazaros, Ball State University,ejlazaros@bsu.edu \\ Jensen Zhao, Ball State University,jzhao@bsu.edu
}

\begin{abstract}
The purpose of this study was to provide comparisons of the " $D$," " $F$," and " $W$ " grades between traditional and online information systems courses for the past five academic years of 2012 to 2017. During this five-year period, five courses were offered by the Information Systems and Operations Management Department at a mid-sized, Midwestern university. These five courses were taught both traditionally and online during the fall, spring, and summer semesters. An analysis of historical data revealed numerous areas of significant differences between traditional and online course " $D$," " $F$," and " $W$ " grades. Conclusions from the study are provided, followed by suggestions for further areas of research for information systems educators.
\end{abstract}

Keywords: Information Systems (IS), Online Course Grades, IS and Online Course Grades

\section{INTRODUCTION}

At institutions of higher learning, online course and degree offerings have grown dramatically. According to a report published by the Babson Research Group, online student enrollments in the United States increased 5.6\% between fall of 2015 and fall of 2016 (Seaman, Allen, \& Seaman, 2018). As one out of four students have taken or is currently taking a course online, university planners are focusing on online implementation and administration strategies (Bowers \& Kumar, 2015; Allen, Seaman, Poulin, \& Straut, 2016). The continued expansion of online education, as well as students desire to take courses online, has resulted in significant issues and challenges.

One of the major challenges of online courses and programs is student retention. Online course dropout rates have been reported to be up to seven times higher than traditional courses (Patterson \& McFadden, 2009). Retention becomes especially important when considering those students who have been identified as having a high-risk for failure (James, Swan, \& Daston, 2016). High dropout rates in online courses and programs have been and continue to be a major challenge for all educational institutions (Bawa, 2016; Boston \& Ice, 2011; Gaytan, 2015; Lee \& Choi, 2011; Phirangee \& Malec, 2017).

While advancements in online offerings have provided new learning opportunities for students, high dropout rates remain a concern. Therefore, this study will analyze historical data from the past five academic years (from 2012 to 2017) and compare online course grades of "D," "F," or "W" with comparable traditional courses.

\section{PURPOSE}

Student retention and dropout rates will continue to be a major challenge for universities. As suggested by Bowers and Kumar (2015), high dropout rates in online courses and programs have been and will continue to be an area that must be addressed. James, Swan, and Daston (2016) concurred by stating that retention in online courses is an issue that clearly needs further investigation. Therefore, the purpose of this study was to analyze historical student data 
comparing "D," "F," and "W" grades between traditional and online courses for the 2012 to 2017 academic years. To address this purpose, answers to the following questions were sought:

1. Are there significant differences in " $\mathrm{D}$ " grades between traditional and online undergraduate information systems courses?

2. Are there significant differences in "F" grades between traditional and online undergraduate information systems courses?

3. Are there significant differences in "W" grades between traditional and online undergraduate information systems courses?

\section{PROCEDURES}

The procedures used for analyzing the data and compiling the participants for this study are described in the following section.

\section{Data Analysis}

Historical data from the Office of Institutional Effectiveness at the researchers' university was obtained. As data were not identifiable (archival de-identified), further analysis was approved by the researchers' Institutional Review Board (IRB) with an exempt classification. Historical data included the academic years of 2012 to 2013, 2013-2104, 20142015, 2015-2016, and 2016-2017. To address the research questions, differences between traditional and online information systems "D," "F,", and "W" course grades were identified by running Pearson's Chi Square test. All tests of significance were determined at the .05 alpha levels.

\section{Participants}

The participants for this study consisted of students enrolled in five courses offered by the Information Systems and Operations Management Department at a mid-sized, Midwestern university during the past five academic years. These courses included Micro Applications for Business, Business Information Systems, Business Communication, Project Management, and Operations Management. These courses were the only courses in the department that were offered in both a traditional and online format.

\section{FINDINGS}

\section{Research Question One}

Research question one sought to identify any differences in " $D$ " grades between traditional and online information systems courses. Chi-Square was run to test for any areas of significance during the past five academic years.

Fall 2012 to Summer 2013. During the Fall 2012 to Summer 2013 academic year, there were two areas of significant differences in "D" grades between traditional and online information systems courses. In the Project Management and Operations Management courses, significantly more students in online courses received a " $\mathrm{D}$ ” grade as compared to students in traditional courses.

Fall 2013 to Summer 2014. During the Fall 2013 to Summer 2014 academic year, there were three areas of significant differences in "D" grades. In the Business Communication, Project Management, and Operations Management courses, significantly more students in online sections received a " $\mathrm{D}$ " grade as compared to students in traditional offerings.

Fall 2014 to Summer 2015. During the Fall 2014 to Summer 2015 academic year, there were three areas of significant differences in "D" grades between traditional and online information systems courses. In the Business Information Systems, Business Communication, and Operations Management courses, significantly more students in online courses received a "D" grade as compared to students in traditional courses. 


\section{Issues in Information Systems \\ Volume 19, Issue 2, pp. 81-89, 2018}

Fall 2015 to Summer 2016. During the Fall 2015 to Summer 2016 academic year, there were two areas of significant differences in " $D$ " grades. Online students in Project Management and Operations Management courses were significantly more likely to have received a grade of " $\mathrm{D}$ " as compared to students who took these courses traditionally.

Fall 2016 to Summer 2017. During the Fall 2016 to Summer 2017 academic year, there were three areas of significant differences in "D" grades. In the Business Information Systems, Business Communication, and Operations Management courses, significantly more students in online courses received a " $D$ " grade as compared to students in traditional courses.

The analysis of " $D$ " grades between traditional and online information systems courses for the past five academic years is illustrated in Table 1 below.

Table 1. Comparison of "D" Grades Between Traditional and Online Information Systems Courses For the Past Five Academic Years

\begin{tabular}{|c|c|c|c|c|c|}
\hline $\begin{array}{l}\text { Information Systems Courses Taught During } \\
\text { The Past Five Academic Years: }\end{array}$ & $\begin{array}{c}\text { Traditional } \\
\text { Course } \\
\text { D Grades } \\
(\%)\end{array}$ & $\begin{array}{c}\text { Online } \\
\text { Course } \\
\text { D Grades } \\
(\%)\end{array}$ & $\begin{array}{c}\text { Chi- } \\
\text { Square }\end{array}$ & $d f$ & $p$ \\
\hline \multicolumn{6}{|l|}{ Academic Year: Fall 2012 - Summer 2013} \\
\hline Micro Applications for Business & 4.9 & 3.6 & 0.290 & 1 & 0.590 \\
\hline Business Information Systems & 6.1 & 5.4 & 0.075 & 1 & 0.784 \\
\hline Business Communication & 2.1 & 3.4 & 0.564 & 1 & 0.452 \\
\hline Project Management & 3.3 & 14.3 & 6.616 & 1 & $0.010^{*}$ \\
\hline Operations Management & 3.0 & 12.3 & 11.536 & 1 & $0.001 *$ \\
\hline \multicolumn{6}{|l|}{ Academic Year: Fall 2013 - Summer 2014} \\
\hline Micro Applications for Business & 2.6 & 2.9 & 0.016 & 1 & 0.898 \\
\hline Business. Information Systems & 5.2 & 4.8 & 0.038 & 1 & 0.846 \\
\hline Business Communication & 2.7 & 7.1 & 5.258 & 1 & $0.022 *$ \\
\hline Project Management & 1.3 & 7.1 & 5.906 & 1 & $0.015 *$ \\
\hline Operations Management & 4.5 & 15.5 & 16.681 & 1 & $<.001 *$ \\
\hline \multicolumn{6}{|l|}{ Academic Year: Fall 2014 - Summer 2015} \\
\hline Micro Applications for Business & 6.6 & 9.2 & 1.254 & 1 & 0.263 \\
\hline Business. Information Systems & 2.5 & 8.2 & 12.211 & 1 & $<.001 *$ \\
\hline Business Communication & 1.8 & 7.2 & 10.72 & 1 & $0.001 *$ \\
\hline Project Management & 0.0 & 3.1 & 3.771 & 1 & 0.052 \\
\hline Operations Management & 6.6 & 20.4 & 20.259 & 1 & $<.001 *$ \\
\hline \multicolumn{6}{|l|}{ Academic Year: Fall 2015 - Summer 2016} \\
\hline \begin{tabular}{l|l} 
Micro Applications for Business \\
\end{tabular} & 2.6 & 2.0 & 0.153 & 1 & 0.696 \\
\hline Business Information Systems & 2.3 & 4.8 & 2.728 & 1 & 0.099 \\
\hline Business Communication & 2.1 & 3.5 & 0.870 & 1 & 0.351 \\
\hline Project Management & .7 & 5.9 & 5.854 & 1 & $0.016^{*}$ \\
\hline Operations Management & 4.5 & 26.5 & 53.571 & 1 & $<.001^{*}$ \\
\hline \multicolumn{6}{|l|}{ Academic Year Fall 2016 - Summer 2017} \\
\hline Micro Applications for Business & 2.3 & 1.9 & 0.145 & 1 & 0.703 \\
\hline Business Information Systems & 2.5 & 6.0 & 5.393 & 1 & $0.020 *$ \\
\hline Business Communication & 1.7 & 6.2 & 8.946 & 1 & $0.003 *$ \\
\hline Project Management & 4.3 & 3.5 & 0.118 & 1 & 0.731 \\
\hline Operations Management & 4.0 & 11.1 & 9.528 & 1 & $0.002 *$ \\
\hline
\end{tabular}

*Significant at the .05 level. 


\section{Issues in Information Systems}

Volume 19, Issue 2, pp. 81-89, 2018

\section{Research Question Two}

Research question two was asked to identify any significant differences in "F" grades between traditional and online information systems courses. Significance was identified by running a Chi-Square test.

Fall 2012 to Summer 2013. During the Fall 2012 to Summer 2013 academic year, there were three areas of significant differences in " $F$ " grades. In Micro Applications for Business, Business Communication, and Operations Management courses significantly more online students had received an "F" grade as compared to students in traditional courses.

Fall 2013 to Summer 2014. During Fall 2013 to Summer 2014 academic year, there were four areas of significant differences in "F" grades. In all instances of significance, students in online courses were more likely to have received a grade of "F" as compared to students in traditional courses. These courses were Business Information Systems, Business Communication, Project Management, and Operations Management.

Fall 2014 to Summer 2015. During the Fall 2014 to Summer 2015 academic year, there were three areas of significant differences. Students in online sections of Micro Applications for Business, Business Communication, and Operations Management courses were more likely to have received a grade of " $F$ " as compared to students in traditional courses.

Fall 2015 to Summer 2016. There were five areas of significand differences in "F" grades between information systems traditional and online courses during the Fall 2015 to Summer 2016 academic year. In all instances of significance, students in online courses were more likely to have received a grade of "F" as compared to students in traditional courses. These courses included Micro Applications for Business, Business Information Systems, Business Communication, Project Management, and Operations Management.

Fall 2016 to Summer 2017. During the Fall 2016 to Summer 2017 academic year, there were three areas of significant differences in " $F$ " grades. Online students were more likely to have received a grade of " $F$ " in Micro Applications for Business, Business Information Systems, Business Communication, and Operations Management, as compared with students in traditional courses.

The analysis of "F" grades between traditional and online information systems courses for the past five academic years is illustrated in Table 2 below. 


\section{Issues in Information Systems}

Volume 19, Issue 2, pp. 81-89, 2018

Table 2. Comparison of "F" Grades Between Traditional and Online Information Systems Courses

For the Past Five Academic Years

\begin{tabular}{|c|c|c|c|c|c|}
\hline $\begin{array}{l}\text { Information Systems Courses Taught During } \\
\text { The Past Five Academic Years: }\end{array}$ & $\begin{array}{c}\text { Traditional } \\
\text { Course } \\
\text { F Grades } \\
(\%)\end{array}$ & $\begin{array}{c}\text { Online } \\
\text { Course } \\
\text { F Grades } \\
(\%)\end{array}$ & $\begin{array}{c}\text { Chi- } \\
\text { Square }\end{array}$ & $d f$ & $p$ \\
\hline \multicolumn{6}{|l|}{ Academic Year: Fall 2012 - Summer 2013} \\
\hline Micro Applications for Business & 5.2 & 10.7 & 4.370 & 1 & $0.037 *$ \\
\hline Business Information Systems & 4.4 & 8.6 & 3.070 & 1 & 0.080 \\
\hline Business Communication & 0.6 & 6.8 & 18.110 & 1 & $<.001^{*}$ \\
\hline Project Management & 2.2 & 0.0 & 1.888 & 1 & 0.169 \\
\hline Operations Management & 1.9 & 10.5 & 13.674 & 1 & $<.001^{*}$ \\
\hline \multicolumn{6}{|l|}{ Academic Year: Fall 2013 - Summer 2014} \\
\hline Micro Applications for Business & 2.6 & 4.8 & 1.525 & 1 & 0.217 \\
\hline Business Information Systems & 3.6 & 11.2 & 13.786 & 1 & $<.001^{*}$ \\
\hline Business Communication & 1.2 & 5.3 & 7.756 & 1 & $0.005^{*}$ \\
\hline Project Management & 0.0 & 6.1 & 9.621 & 1 & $0.002 *$ \\
\hline Operations Management & 1.5 & 16.5 & 46.644 & 1 & $<.001^{*}$ \\
\hline \multicolumn{6}{|l|}{ Academic Year: Fall 2014 - Summer 2015} \\
\hline Micro Applications for Business & 3.7 & 10.8 & 13.394 & 1 & $<.001^{*}$ \\
\hline Business Information Systems & 3.4 & 6.2 & 2.516 & 1 & 0.113 \\
\hline Business Communication & 0.9 & 7.2 & 18.372 & 1 & $<.001^{*}$ \\
\hline Project Management & 0.8 & 4.2 & 2.588 & 1 & 0.108 \\
\hline Operations Management & 1.3 & 15.0 & 43.891 & 1 & $<.001^{*}$ \\
\hline \multicolumn{6}{|l|}{ Academic Year: Fall 2015 - Summer 2016} \\
\hline Micro Applications for Business & 3.5 & 11.5 & 19.504 & 1 & $<.001^{*}$ \\
\hline Business Information Systems & 2.9 & 7.3 & 5.959 & 1 & $0.015^{*}$ \\
\hline Business Communication & 0.7 & 2.8 & 3.890 & 1 & $0.049 *$ \\
\hline Project Management & 0.7 & 9.3 & 10.785 & 1 & $0.001 *$ \\
\hline Operations Management & 1.6 & 14.2 & 36.024 & 1 & $<.001^{*}$ \\
\hline \multicolumn{6}{|l|}{ Academic Year Fall 2016 - Summer 2017} \\
\hline Micro Applications for Business & 3.6 & 15.5 & 41.241 & 1 & $<.001^{*}$ \\
\hline Business Information Systems & 2.0 & 5.4 & 5.748 & 1 & $0.017 *$ \\
\hline Business Communication & 0.9 & 6.2 & 15.569 & 1 & $<.001^{*}$ \\
\hline Project Management & 2.5 & 2.6 & 0.007 & 1 & 0.935 \\
\hline Operations Management & 1.7 & 9.4 & 18.32 & 1 & $<.001^{*}$ \\
\hline
\end{tabular}

*Significant at the 05 level.

\section{Research Question Three}

Research question three sought to discover any significant differences in "W" grades between traditional and online information systems courses. To test for any areas of significance during the past five academic years, a Chi-Square was performed.

Fall 2012 to Summer 2013. During the Fall 2012 to Summer 2013 academic year, there were four areas of significant differences in "W" grades between traditional and online information systems courses. In the four cases, students enrolled in online Micro Applications for Business, Business Information Systems, Project Management, and Operations Management courses, were significantly more likely to have withdrawn (received a grade of "W") as compared to students in traditional courses. 


\section{Issues in Information Systems \\ Volume 19, Issue 2, pp. 81-89, 2018}

Fall 2013 to Summer 2014. During the Fall 2013 to Summer 2014 academic year, again there were four areas of significant differences in "W" grades, although the courses differed slightly. In all instances of significance, students in online courses were more likely to have withdrawn (received a grade of "W") as compared to students in traditional courses. These courses included Micro Applications for Business, Business Information Systems, Business Communication, and Operations Management

Fall 2014 to Summer 2015. During the Fall 2014 to Summer 2015 academic year, there were three areas of significant differences in "W" grades between traditional and online information systems courses. In the Micro Applications for Business, Business Information Systems, and Operations Management courses, significantly more students in online courses withdrew from the course (received a "W") grade as compared to students in traditional courses.

Fall 2015 to Summer 2016. During the Fall 2015 to Summer 2016 academic year, there were again three areas of significant differences in "W" grades between information systems traditional and online courses. Just as in the previous academic year, students in online courses of Micro Applications for Business, Business Information Systems, and Operations Management were more likely to have withdrawn (received a grade of "W") as compared to students in traditional courses.

Fall 2016 to Summer 2017. During the Fall 2016 to Summer 2017 academic year, there were two areas of significant differences in "W" grades between information systems traditional and online courses. As in previous years, significantly more students in online courses withdrew from the course (received a "W" grade) as compared to students in traditional courses. These courses included Micro Applications for Business and Operations Management.

The analysis of "W" grades between information systems traditional and online courses for the past five academic years is illustrated in Table 3 below. 


\section{Issues in Information Systems}

Volume 19, Issue 2, pp. 81-89, 2018

Table 3. Comparison of "W" Grades Between Traditional and Online Information Systems Courses

For the Past Five Academic Years

\begin{tabular}{|c|c|c|c|c|c|}
\hline $\begin{array}{l}\text { Information Systems Courses Taught During } \\
\text { The Past Five Academic Years: }\end{array}$ & $\begin{array}{c}\text { Traditional } \\
\text { Course } \\
\text { W Grades } \\
(\%)\end{array}$ & $\begin{array}{c}\text { Online } \\
\text { Course } \\
\text { W Grades } \\
(\%) \\
\end{array}$ & $\begin{array}{c}\text { Chi- } \\
\text { Square }\end{array}$ & $d f$ & $p$ \\
\hline \multicolumn{6}{|l|}{ Academic Year: Fall 2012 - Summer 2013} \\
\hline Micro Applications for Business & 5.3 & 13.1 & 8.310 & 1 & $0.004 *$ \\
\hline Business Information Systems & 3.2 & 12.9 & 18.929 & 1 & $<.001 *$ \\
\hline Business Communication & 2.3 & 4.5 & 1.432 & 1 & 0.231 \\
\hline Project Management & 5.6 & 20.2 & 8.480 & 1 & $0.004 *$ \\
\hline Operations Management & 3.0 & 38.6 & 101.566 & 1 & $<.001 *$ \\
\hline \multicolumn{6}{|l|}{ Academic Year: Fall 2013 - Summer 2014} \\
\hline Micro Applications for Business & 2.3 & 7.6 & 9.532 & 1 & $0.002 *$ \\
\hline Business Information Systems & 2.3 & 12.8 & 32.634 & 1 & $<.001 *$ \\
\hline Business Communication & 1.0 & 8.8 & 22.969 & 1 & $<.001 *$ \\
\hline Project Management & 5.2 & 8.1 & 0.872 & 1 & 0.350 \\
\hline Operations Management & 3.0 & 14.6 & 23.079 & 1 & $<.001 *$ \\
\hline \multicolumn{6}{|l|}{ Academic Year: Fall 2014 - Summer 2015} \\
\hline Micro Applications for Business & 2.7 & 8.5 & 11.796 & 1 & $0.001 *$ \\
\hline Business Information Systems & 3.5 & 11.0 & 14.972 & 1 & $<.001 *$ \\
\hline Business Communication & 3.2 & 5.2 & 1.381 & 1 & 0.240 \\
\hline Project Management & 4.2 & 7.3 & 0.963 & 1 & 0.327 \\
\hline Operations Management & 2.0 & 22.1 & 65.282 & 1 & $<.001 *$ \\
\hline \multicolumn{6}{|l|}{ Academic Year: Fall 2015 - Summer 2016} \\
\hline Micro Applications for Business & 2.7 & 10.1 & 20.700 & 1 & $<.001 *$ \\
\hline Business Information Systems & 2.0 & 6.5 & 8.173 & 1 & $0.004 *$ \\
\hline Business Communication & 1.6 & 3.5 & 1.804 & 1 & 0.179 \\
\hline Project Management & 2.1 & 5.1 & 1.675 & 1 & 0.196 \\
\hline Operations Management & 3.6 & 13.3 & 16.028 & 1 & $<.001 *$ \\
\hline \multicolumn{6}{|l|}{ Academic Year: Fall 2016 - Summer 2017} \\
\hline Micro Applications for Business & 3.9 & 9.9 & 11.623 & 1 & $0.001 *$ \\
\hline Business Information Systems & 3.8 & 5.4 & 0.793 & 1 & 0.373 \\
\hline Business Communication & 2.3 & 2.8 & 0.123 & 1 & 0.726 \\
\hline Project Management & 3.1 & 3.5 & 0.036 & 1 & 0.849 \\
\hline Operations Management & 1.2 & 8.5 & 19.257 & 1 & $<.001 *$ \\
\hline
\end{tabular}

*Significant at the 05 level.

\section{LIMITATIONS}

Participants for this study were undergraduate students enrolled at a mid-sized, Midwestern univeristy. These participants had taken information systems courses either in a traditional or online learning environment during the past five academic years. These findings might not be the case for other clases and degrees. The following conclusions are offered in accordance with these limitations.

\section{CONCLUSIONS}

Research question one identified any significant differences between information system traditional and online "D" grades during the past five academic years. For the five information system courses that were offered in both traditional and online format, two to three areas of significant differences were found between recorded " $D$ " grades in each of 
the five academic years. In each instance, students in online information systems courses were significantly more likely to receive a grade of " $D$ " when compared to students in traditional courses.

Research question two identified significant differences between information system traditional and online " $F$ " grades during the past five academic years. Each year, a span of three to five areas of significant differences were found in "F" grades between traditional and online information systems courses. In all cases, students in online information systems courses were significantly more likely to receive a grade of "F" when compared to students in traditional courses.

Research question three identified any significant differences between information system traditional and online "W" grades during the past five academic years. Two to four areas of significant differences were found each year between recorded "W" grades in the five information system courses. In each occurrence, students in online information systems courses were significantly more likely to withdraw when compared to students in traditional courses.

Students want opportunities to take online versions of traditional courses. Although this type of learning seems very enticing to students, they might not have the skills, maturity, or self-discipline to succeed without the face-to-face teacher instructions and help. In addition, students in online courses could feel isolated or disconnected from their classmates and course, which is much less likely to occur in the traditional classroom. Information systems educators involved with advising students who are interested in taking online courses should make sure to stress the differences between traditional and online courses, and the special characteristics of online learning.

Information systems educators need to be cognizant of the low grades and high dropout rates in online courses. Online courses should be continuously reviewed to identify any potential problems in course design that appear to be causing difficulties for students. The lack of social connectedness inherent in online courses could be one plausible reason why some students don't perform as well in online environments as they do in the traditional classroom. One challenge for online information systems educators is to find methods for keeping students socially connected with other students, as well as establishing a strong teacher presence, to create positive learning experiences.

\section{RECOMMENDATIONS FOR FURTHER RESEARCH}

Based on the findings from this study, additional areas of research for information systems educators and practitioners are suggested:

1. As online offerings and enrollments increase, challenges dealing with student success will continue to be a critical area of study. Similar studies of this nature, comparing traditional and online course grades, should be replicated in five years to identify if differences in "D," "F," and "W" grades associated with these courses change over time.

2. This study focused on differences between information systems traditional and online grades of "D," "F," and "W." Further research should be conducted to determine the degree of success rates (grades of "A,", "B,", and "C") between traditional and online courses.

3. As this study revealed so many significant differences between traditional and online course low and failing grades, further research should be conducted with other variables such as SAT scores, GPA, gender, age, or class level that may help to explain these differences.

4. As the incidences of low grades in online courses is greater than traditional grades, further study should investigate potential problem areas such as course design, student connectedness, and methods of interaction between students and teachers.

5. As this study was conducted using information systems courses at one mid-sized, Midwestern university, future studies should identify if this is the case with other online courses and programs at various institutional settings.

6. Rates of low grades in online courses are disturbing. Information systems practitioners should conduct similar studies to explore implementable solutions for those involved with online course offerings. 


\section{Issues in Information Systems}

Volume 19, Issue 2, pp. 81-89, 2018

\section{REFERENCES}

Allen, I. E., Seaman, J., Poulin, R., \& Straut, T. (2016, February). Online report card: Tracking online education in the United States. Babson Survey Research Group and Quahon Research Group, LLC. Retrieved from http://onlinelearningsurvey.com/reports/onlinereportcard.pdf

Bawa, P. (2016). Retention in online courses exploring issues and solutions - a literature review. Retrieved from https://doi.org/10.1177/2158244015621777

Bowers, J., \& Kumar, P. (2015). Students' perceptions of teaching and social presence: a comparative analysis of face-to-face and online learning environments. International Journal of Web-Based Learning and Teaching Technologies, 10(1), 27-45.

Gaytan, J. (2015) Comparing faculty and student perceptions regarding factors that affect student retention in online education. American Journal of Distance Education, 29(1), 56-6. DOI: 10.1080/08923647.2015.994365

Heyman, E. (2010). Overcoming student retention issues in higher education online programs. Online Journal of Distance Learning Administration, 13(4). Retrieved from https://www.westga.edu/ distance/ojdla/winter134/heyman134.html

James, S., Swan, K., \& Daston, C. (2016). Retention, progression and the taking of online courses. Online Learning, 20(2). Retrieved from https://onlinelearningconsortium.org/jaln_full_issue/online-learning-journal-volume20-issue-1-march-2016/

Lee, Y., \& Choi, J. (2011). A review of online course dropout research: implications for practice and future research. Educational Technology Research and Development, 59(5), 593-618.

Patterson, B., and C. McFadden. (2009). Attrition in online and campus degree programs. Online Journal of Distance Learning Administration 12(2). Retrieved from http://www.westga.edu/ distance/ojdla/summer122/patterson112.html

Phirangee, K; Malec, A. (2017). Othering in online learning: an examination of social presence, identity, and sense of community. Distance Education (38)2. 160-172.

Seaman, J. E., Allen, I. E., \& Seaman, J. (2018). Grade increase: Tracking distance education in the United States. Babson Survey Research Group. Retrieved from http://www.onlinelearningsurvey.com/highered.html 